\title{
EUROPEAN POSTHUMAN BORDER IMAGE: PERFORMATIVITY, CREATIVITY AND BEYOND
}

\author{
Basia NIKIFOROVA* \\ Lithuanian Culture Research Institute, Department of Contemporary Philosophy, \\ Saltoniškiu str. 58, LT-08105 Vilnius, Lithuania
}

Received 2 August 2018; accepted 21 November 2018

\begin{abstract}
To artists, border is not just a physical reality imposed on the landscape by political forces, but also a subject for imagination and creativity, representation and visualization. Presentation of migration, refugees and growing new ethnic and religious communities is important for visual arts. Our task is to discuss the correlativeness between the new form of city bordering and reterritorialization and their materialized visual image, to reflect the balance between claims of difference and sameness and the dynamics between dominant perceptions and refugees' self-representations. Nowadays in the media, we deal with the Debordian spectacle which reduces reality to an endless fragmentation, while encouraging us to focus on appearances. Thomas Neil notes that the migrant has become the political figure of our time, and migrant phenomena invite us to rethink the fundamental political, cultural and art philosophy. It is important to reveal the interconnections between new discourses and art practices, reflecting on the local Lithuanian image of the migration process. Thus, the case study of the research represents an analysis of Sigita Maslauskaitè-Mažylienè (Lithuania) artworks and artistic practices as important discursive processes and cultural meanings.
\end{abstract}

Keywords: border, creativity, image, migration, representation, reterritorialization, visual arts.

"The boundary is a function of the relation, a brokering of difference, a negotiation in which I am bound to you in my separateness" (Butler, 2009, p. 44).

\section{Introduction}

The subject of migration, refugees and citizenship is gaining significance in visual arts (VAs). Our analysis will look at the criticism of the popular argument that the importance of closing borders to outsiders is that this exclusion is necessary in order to preserve a state's distinctive culture. The territory-oriented rhetorics popular in our region pose the idea that culture boundaries are facing a great challenge in the society consisting of multiple ethnic groups. The challenge occurs due to the intense contacts between various cultural carriers that blur the clarity of demarcation lines. The common archeology of memory (AM) implies that Europe is always home to tensions among numerous religious, cultural and linguistic

${ }^{\star}$ Corresponding author. E-mail: nikiforovaphilosophy@gmail.com 
identities as well as multiple readings of history. Nevertheless, the new image of territorial transgression was realized and started to be obvious in the second decade of the 21st century. "Migration must be understood in a broad sense" (Papastergiadis, 2000). Postmodern art intuitively reflects the conclusion of famous researchers of borders that, after some decades of European deterritorialization, we have observed the tendency of reterritorialization. It factually means that there has been a process towards strengthening the borders which were previously weakened.

Visual imagery is of particular importance for politics because it is one of the ways for news from distant places to reach home, while the notion of "home" is being deconstructed. In this sense, performativity is not an invitation to turn everything into words; on the contrary, performativity is precisely a contestation of the excessive power granted to language to determine what is real. Visual image allows to consider the virtual border image as a sociological site and migration as a historical constant. The unambiguity of such once-stable entities as culture, civilization, nation and border is relativized. The penchant for dissimilarity was first reflected in the VAs that reconceptualized the image of the human being, nature, matters and the interconnection between them.

Artworks are visual objects whose function is to create a frame of intentions and interpretations in the cultural and social context. The relationship between art and politics has become significantly more complex. The following cases of artists show that there are instances when creativity has great possibilities to bring a change into the world through visual and narrative images.

\section{Border and its image as an unfinished project}

In an increasingly diasporic world, borders are the entangled reality for all of the involved in this process and have become "a new normality". The contemporary meaning of European external borders covers survival, resistance, an attempt to escape from the armed conflicts, ongoing violence, persecution and instability in the origin countries, ecological disasters and economic difficulties.

The questions of migration and borders are at the core of critical, radical geography and new materialism. One of the pillars of the new materialism is the claim that modern natural science and postmodern cultural theory are both humanisms. Rosi Braidotti offers a new way to rescue the studies of humanities:

\footnotetext{
"My general hypothesis is simple: the Humanities can and will survive their present predicament and contradictions to the extent that they will show the ability and willingness to undergo a major process of transformation in response to both technological advances and geo-political developments. The Humanities therefore need great creativity to cope with these challenges" (2013, p. 188).
}

The need for great creativity incites a new way of thinking about Europe's borders and the challenged necessity of a provocative and timely reflection on the debate of border security and migration management in Europe. All of that immediately finds a response in researching literature that offers critical perspectives on current migration policies, detention and deportation, border control. Globalization has had its effect: contemporary borders appear to be more 
differentiated, and their meaning is changing. With the increase of European integration, the nature of boundaries and borders has altered, their functions are rapidly transforming, "creating a situation that demands careful analysis, considering boundaries and cross-boundary interactions at different levels [...] as a single system" (Kolossov, 2005, p. 628). Gilles Deleuze and Félix Guattari spoke of the two general tendencies: "territorialization" and "deterritorialization", which are very important for the philosophical analysis of the meaning of borders. They wrote that "capitalism is continually reterritorializing with one hand what it is deterritorializing with the other" (Deleuze \& Guattari, 1983, p. 259). Now it is possible to distinguish three tendencies in the dialectical processes at borders: territorialization, deterritorialization and reterritorialization. Two of them appear to oppose each other, while being reciprocal processes in the European territory: the disappearance and strengthening of borders happens simultaneously. Both deterritorialization and territorialization are processes which are going on and developing not only on the physical, but also on the psychological territory, where the status of a relationship between groups or individuals is designated. They divide the processes of deterritorialization into relative and absolute. To him, the relative deterritorialization constitutes a possibility of reterritorialization or returning to the past situation.

As a philosophical approach, new materialism suggests viewing border as a space where past and future are permanently clashed. The simple linear time dimension does not work there. Braidotti points out that "we already live in permanent states of transition, hybridization and nomadic mobility, in emancipated (postfeminist), multiethnic societies with high degrees of technological mediation" (2013, p. 198). Events that occur within such societies are neither simple, nor linear; they rather represent multilayered and internally contradictory phenomena. The linear time that means rejection from changes and "leaves the structure of power basically untouched" is the Postulated Chronos; on the other hand, the Postulated Aion is the non-linear time that means actualization of connection and interdependence between past, present and future (Braidotti, 2016, p. 31).

The three observed tendencies of territorialization, deterritorialization and reterritorialization replace each other in a continuous sequence. It is not that past is what happened before, and future is what will unfold, but rather, past and future are iteratively reconfigured and enfolded through the world's ongoing intra-activity. This interplay of past and future influences the axiological interpretation of border, evaluation and rethinking the functions of borders (Barad, 2003, 2007). The new philosophical approach prepared border theory for the new reality of the last decade that has marked the highest number of migrations in recorded history.

\section{The figure of the migrant: multiple performativity}

Constrained by environmental, economic, and political instability, scores of people are on the move. "The migrant has become the political figure of our time" (Nail, 2015, p. 235), although it is the one least defined by its being, place, and more by its becoming and displacement: by its movement. To Nail, the author of the book The Figure of the Migrant (FM, 2015), migration as such means a situation that is neither entirely free nor forced - both characteristics are typical of the same regime of social motion. The regime of social motion 
endows the migratory figure such features as mobile social positions and not fixed identities. Nail emphasizes these important aspects, which, according to him, reflect the defining feature of social motion: its movement. The migrant has been predominantly understood from the perspective of stagnation, perceived as a secondary or derivative figure; the migrant is not a figure without its own history and social force.

The present era of growing globalization and the European border crisis disintegrates sociological, political and philosophical analyses. During the last years, Vaughan-Williams and Neil, among others, have been trying to revise such important notions as refugees, migrant, migration and dehumanization through a biopolitical paradigm. They offer new hypotheses for contemporary border studies, which provide a possibility to reconceptualize the meaning of border as such and its general actors. At the same time, they are carefully considering the long-time history of the border and the attempts to provide a counter-history of the migrant by prioritizing movement. Nail starts out with theological arguments from the Biblical times (the mythic expulsion of Adam and Eve from the garden, Yahweh's preference for the nomadic Cain rather than the settled on territory Abel).

To Nail, the migrant not only is an empirical figure but also signifies a new model of political membership. He remarks that migrant phenomena invite us to rethink and deconstruct the fundamentals of political and cultural philosophy. Nail reinterprets the history of political power from the perspective of movement that defines the migrant in the first place. The next fresh tool for the analysis of contemporary migration is his concept of kinopolitics that involves major historical conditions (territorial, political, juridical, and economic) and figures of migration (the nomad, the barbarian, the vagabond, and the proletariat):

"Kinopolitics is the politics of movement, from the Greek word 'kino', meaning movement. If we are going to take the figure of the migrant seriously as a constitutive, and not derivative, figure of Western politics, we have to change the starting point of political theory. Instead of starting with a set of preexisting citizens, kinopolitics begins with the flows of migrants and the ways they have circulated or sedimented into citizens and states - as well as emphasizing how migrants have constituted a counter-power and alternative to state structures. In short, kinopolitics is the reinvention of political theory from the primacy of social motion instead of the state" (Nail \& Settle, 2016).

This social theory of movement begins with the assumption that human groups function primarily as flows or a continual movement. In Nail's view, this territorial ordering is what produces the migrant, which varies over time but remains the expelled other. The pedetic social force coexists in an undivided social distribution alongside other forms of motion. Nail took the example of ink that "does not divide the water as something else but diffuses and becomes ink-water" and used this idea to reconsider the material manifestation of today's illegal migrant (2015, p. 125). The illegal migrant is shaped by various turbulence regimes in a continuous process, which makes it impossible to remove discrete parts of the figurein-motion. Further, "the power relations that shape the asylum seeker can become the same forces that (re)shape this abject figure" (Westmoreland, 2016, p. 156). During a roundtable discussion on the book FM, Ariana Novoa noted that "if we ignore how over the last two centuries the mobility of bodies has been restricted according to their external characteristics, we cannot expect to explain the dynamics of border" (Westmoreland, 2016, p. 156). From 
her point of view, it is impossible to understand and explain the inequality of humans and its connection with kinetic power, as well as the dynamics of human movement, without racial divisions. This remark is very important to us when we speak about the figure of the migrant (FM). Racial divisions become a striking dimension of migrant movement and an important part of its multiple wholeness (MW).

We define the FM as a political concept that identifies the common points where mobile figures are socially expelled or dispossessed as a result, or as the cause, of their mobility. The movement of the migrant does not simply comprise reaching point $\mathrm{B}$ from point $\mathrm{A}$; it is the constitutive condition for the qualitative transformation of society as a whole. Looking on the migrant as a figure, which is not a fixed identity or specific person but a mobile social position, we find him/her as a social persona that bears many masks depending on the relative social conditions of expulsion.

At the same time, we find that his/her human image has race specificities and religious belonging. Both of these indications of identity are visible through appearance: the color of skin, face, body, clothes and headwear. The process of differentiation is a starting point for the imagination of otherness as such. A social body begins with the formation of a common space or territory. The process of territorialization is a stage at which a human being is configured with space, such as a continent, or with its area.

Jens Rydgren analyses the perception of immigration as a threat through the fear of the physically different other. It is partly related to racism in the traditional sense, as an ideology claiming fundamental inequality based on biological difference (Rydgren, 2004, p. 124, 2008, p. 743). Rydgren suggests differentiating between immigration skepticism and xenophobic attitudes (2017, p. 486).

The FM constantly balances between image and performativity. A posthuman performative understanding of discursive practices challenges not only the representationalist belief in the power of words to represent preexisting things; on the contrary, performativity is precisely a contestation of the excessive power granted to language to determine what is real. VAs use posthuman performance as a type of interventionism that explores social relationships and transformation outside the parameters of humanism. Posthuman representationalism (PHR) is an attempt to look on the FM as a MW: mind, soul, body, gender, religion, ethnicity, race and social status.

\section{Border image: between creativity and social activism}

The current discussions about border, migration crises and refugees are in large part centered on the question of art activism (AA) that means the ability of art to function as a space and medium for protest and social activism (SA). Boris Groys considers the phenomenon of $\mathrm{AA}$ as a novel phenomenon which is quite different from the phenomenon of critical art that has become familiar to us during the recent decades. In his view, art activists want "to change political and social conditions by means of art - not so much inside the art system but outside it, in reality itself" (Groys, 2014).

AA is often criticized as a phenomenon in which the arguments of morality and justice dominate over artistic quality. Such a view correlates with Guy Debord's (1995) ideas about 
the aestheticization and spectacularization of politics that divert attention away from the practical goals of political protest and towards its aesthetic form. In this case, art departs from its important mission as a medium of a true, inartificial political protest. Art is used as a political action is converted into pure aesthetics and a spectacle. Famous artists Ai Weiwei, Artur Zmijewski and Krzysztof Wodiczko, among others, are often put to blame for such a transition.

Debord announced the onset of the spectacle in his book The Society of the Spectacle (1995, in French: La société du spectacle, originally published in 1967). Even today, it remains a great theoretical work about the contemporary role of mediation in social, cultural and artistic practice. In his later Comments on the Society of the Spectacle (1998, in French: Commentaires sur la société $d u$ spectacle, originally published in 1988), Debord argued that everything he had written in 1967 was still true, only with one major exception: the society of the spectacle had reached a new form. In fact, some of his remarks and conclusions about the aestheticization and spectacularization of social and political life are significant and useful for analyses of border and migration processes.

The quick changes on the European borders look like a spectacle whose last act has not yet started. In its actual phase, the European borders are a transitional object and an object of permanent transgression. In the present time, Debord's situationist theory reveals to us that "when the real world changes into simple images, the simple images become real beings and effective motivations of hypnotic behavior" and "every society which eliminates geographical distance reproduces distance internally as spectacular separation" (1995, thesis 18).

The contradiction between humanitarianism and border security starts to be the subject of activity in the international visual and narrative arts. The new materialist turn has stimulated a reconsideration of the art narrative.

In addition, we are to give the answer to the question "What is mystery of fact?". It emerges through overcoming the representational and narrative clichés and one-dimensional representation. Deleuze calls it the vital intuition (VI) of the time-image. This VI is delved into by Tommy Wieringa, the winner of the 2013 Libris Prize, in his poetic novel about refugees' journeys These Are the Names (2012, in Dutch: Dit zijn de namen). Wieringa's tale treads restlessly between genres, sometimes stepping into the haunted territory of myth. He presents several migrating characters that have fallen victim to human trafficking. The border that these migrants so desperately want to cross, and that they in the end believe to have crossed, does not really exist. This border is not the national border the migrants wanted to cross to flee depressing conditions, but a constructed and virtual border. Their Exodus to the Promised Land in reality is a big lie of traffickers who faked the border with all its attributes: guards and dogs. Why is it such an important narrative? First, it is the symbolic image of posthuman approach in the narrative form. Second, Wieringa uses the figures or characters of migration, animals, nature's materiality and spirituality, feministic inclusions to create a global surrealistic image of the contemporary world (2012). Third, Wieringa's novel is a poetic illustration of such notions as "diffraction", "entangled world", "non-place", which become a metaphor for every kind of critical consciousness. The characters of the novel destroy the uniform migrant image and show that a social persona bears in self many masks depending on the relative social conditions of expulsion. 
The movie Human Flow (HF, 2017) by iconic Chinese artist and filmmaker Weiwei features the "moment of now", ignoring distance and showing the presence of thousands of people who move around the planet. $H F$ is a witness to its subjects and their desperate search for safety, shelter and justice. For Weiwei, there are no forbidden places or space: he films in refugee camps and the perilous ocean crossings to barbed-wire borders. He shows the dislocation and disillusionment with courage, endurance and adaptation, the ruin of the so-close past and the unknown potential of the future. The audience clearly feels presence instead of distance, immersion instead of contemplation, entanglement or diffraction instead of representation, emotions instead of language, touching instead of perception. Weiwei touches these bodies, hugs them, eats with them, shaves and shears them, and these actions are mutual. In HF, migrants stop to be sunflower seeds, which are indistinguishable in their mass, and start to be the object of tolerance, compassion and trust. His motto is "There's no refugee crisis, only a human crisis".

The two discussed cases open up a great possibility in art for making a change in the world for the better and the more rightful.

\section{To get rid of oneself}

Not every painting tells a story; sometimes it is barely a static image. Which tools can artists use to create a story or message that stimulates emotions, or to avoid art commodification? Every artist in their own way tries to create a unique metaphorical image that will tell their visual story. Our experience of contemporary art is mediated by text, knowledge of the artist's previous work, and our own visual archives which constitute the archaeology of present.

In an interview to the author of the present article, Lithuanian artist MaslauskaitèMažyliene explains that her path to the subject of refugees originated in the personal family history (Maslauskaitè-Mažylienè \& Nikiforova, 2018). Through a long period of reflection, she has realized that the stories about Siberia and the deportees had surrounded her since childhood. The Biblical themes that have long been the subject of her painting also often indicate the presence of the topic of exile around her. She felt the desire to get rid of herself, to escape from herself in order to survive. In various areas, this topic was of concern to her, but only the events of recent years in Europe, the turmoil in the Middle East, the media outlets for refugee flows have finally pushed and inspired Maslauskaite-Mažyliene with the desire to implement the project By the Rivers of Babylon. Refugees and Deportees $(R B R D)$ in the following forms (see Figures 1-3):

- During Vilnius Culture Night 16 June, 2017 the artistic event RBRD. St. Stephen's Church: Image, Sound, Space was presented in St. Stephen's Church (Vilnius, Lithuania). Paintings of refugees (from Adam and Eve to Alepo's Boy) were displayed in the places of destroyed altars of the inactive church, the Gregorian chant choir of the Vilnius Cathedral Schola Gregoriana Vilnensis chanted psalms of exile and longing, and the Syrian art critic Farah Mohammed introduced contemporary Syrian art;

- The exhibition of paintings and texts written on wooden fragments By the Rivers of Babylon. Letters of Refugees was organized in the Gallery Artifex in Vilnius Academy of Arts in 20 June-8 July, 2017;

- On 5-30 September, 2017 the exhibition and video installation $R B R D$ were being presented in the Gallery Left-Right in Vilnius Graphic Art Centre. 


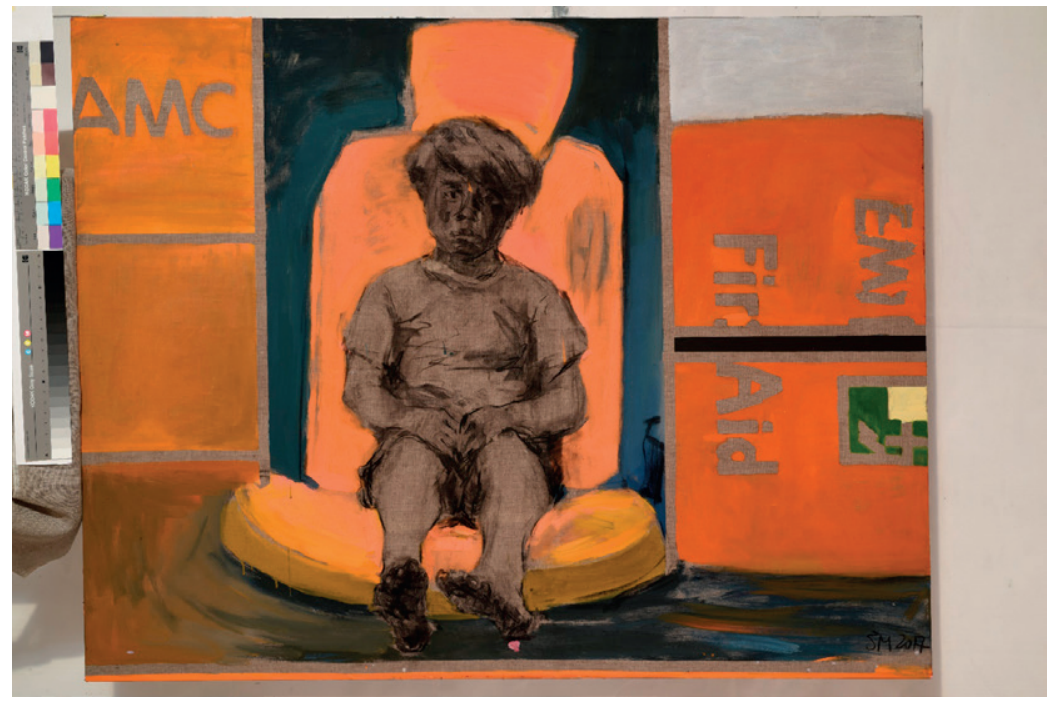

Figure 1. Sigita Maslauskaitè-Mažylienè. A Boy (2017)

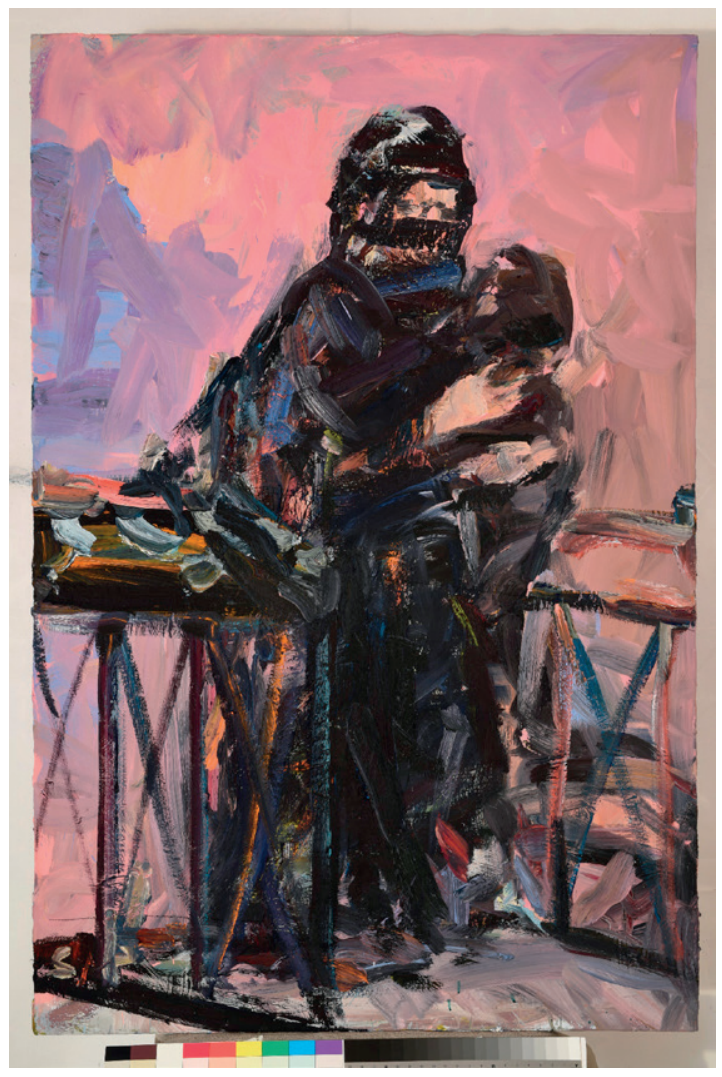

Figure 2. Sigita Maslauskaitè-Mažylienè. Refugee (2017) 


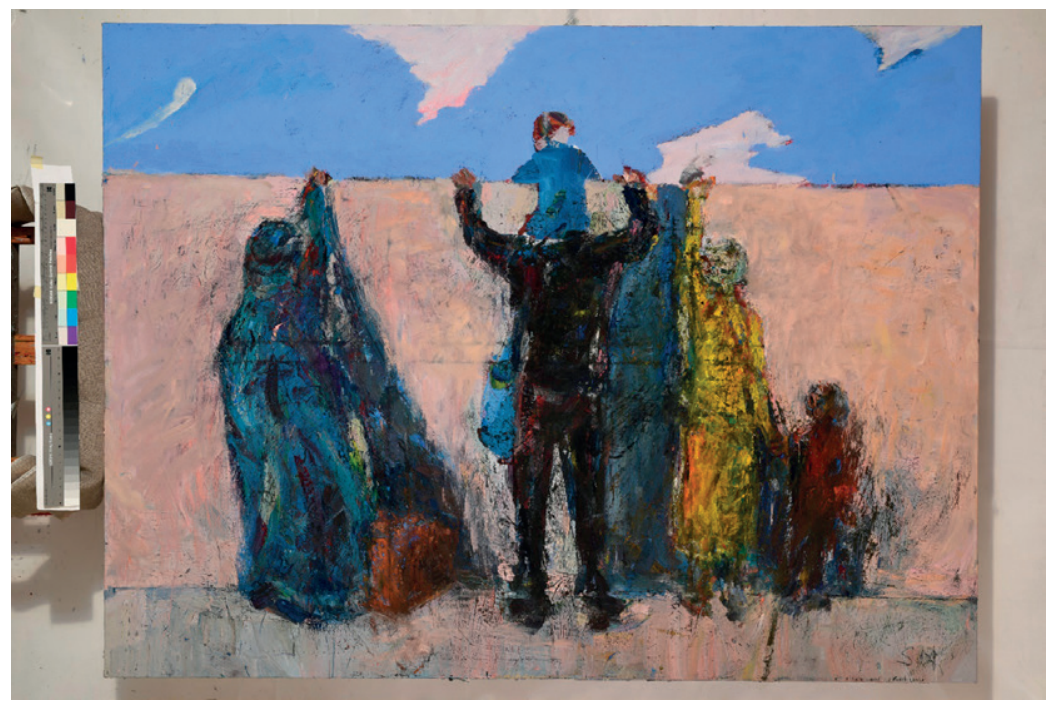

Figure 3. Sigita Maslauskaitè-Mažylienè. Border (2017)

The artist considers the last event as the finishing stage of her phase of reflection on the topic.

The topics we covered at the interview strongly relate to my research and MaslauskaitèMažylienë's artistic activity: borders, AM, deportation and exile, migration, FM, refugees' image and performativity, art creativity, SA and political conjuncture.

In her view, the subject of refugees has always accompanied the European history, and now it is being given a distinctive form, appearance and message in contemporary artworks. She is confident that today's events can be considered applying different methods through the "traditional means" (canvas, oil) that symbolize the interdependence of pre-image and repetition, source of inspiration and replica. She applies her inspiration and creativity in paintings based on both the canonical (classical) story and the mass media visualization and representation of the image of refugees from Syria and/or North Africa. The structure of her exhibition (painted replicas) was based on Hans Belting's statement that "there is a continuous exchange of images and images between living bodies and artificial media". Another Belting's idea about the "widening of the territory of images, together with the opening of the boundaries between different media" helps us understand the logics and structure of the exhibition (Belting, 2005, p. 302, 2014).

Current discussions about migration crises and refugees are centered intensely on the question of AA. Maslauskaitė-Mažylienè interpreted her own refugee project as only partly belonging to the AA: the project and exhibition have been awarded criticism stating a need for "a different mythology and iconography from what we are accustomed to rely on" (Kalinauskaite, 2017). She noted that her exhibitions and performance had received a very wide-ranging and not necessarily favorable feedback from both artists and professionals in the field and ordinary viewers. The project $R B R D$ is an attempt to show the events that have shaken us through their own image and help us find adequate visual language in which we 
can speak. It is an effort to reveal how the images displayed on screens correlate with the theme of refugees in different forms.

Maslauskaitè-Mažylienè finds that creation of exhibitions and images is not sufficient and adequate to form a realization of the horrid experiences of war. She agrees with Kalinauskaitës comments on her work. Nevertheless, Maslauskaitè-Mažylienè believes that image, as a call to the viewer, helps to remember and experience the event. At the same time, she highlights the ambivalence of this experience: endless production and reproduction of images create a situation in which sharp empathy is turning into blunt indifference.

The artist conveyed the feeling of exile and strangeness in her first video film Partition: $\operatorname{Niqab}(P N, 2011)$. It seems that the strangely annoying experience with the images of refugees and the debate around the artistic value of the project have benefited not only the artist but the audience as well.

To my question about the video installation PN (for me it is about the body and its frontiers, about the limited woman's personal space, border and gender) Maslauskaite-Mažylienè gave an unexpected and deeply thought-out response. For her, the video installation $P N$ "is an allegory of partitions and walls" (it says in the Quran: "Speak with them through the divan (niqab)"). "The most interesting thing for me was to participate: to see the human reactions, to observe everything through the narrow gap for the eyes in the headwear [...]". The targeted tourist objects in Lithuania, and particularly Vilnius, are the background, and the strangeness and foreignness of the woman with a niqab is highlighted. In my opinion, this person (not necessarily a woman) is separated physically, socially and emotionally. The human beings' alienation is visible against the background of a Christian and industrial landscape. Invisible walls surround this figure and create a MW of walls. The apparel and gender are the only distinguishable and visible parts; all other (religious, ethnic, racial) identity marks are created by our imagination through the mass media and our social experience (see Figures 4-7).

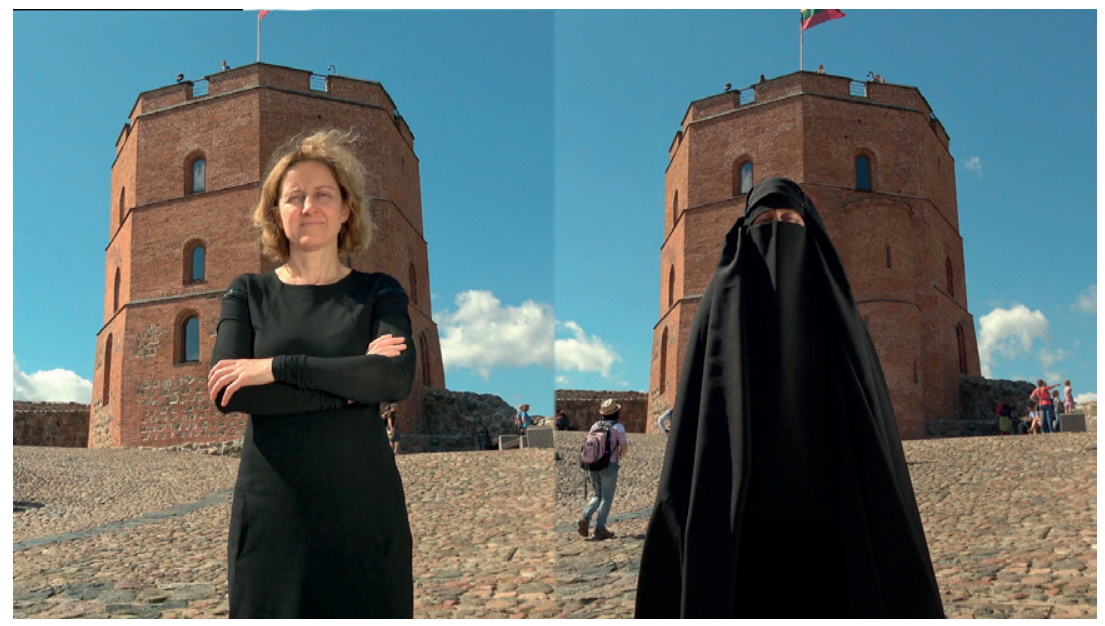

Figure 4. Sigita Maslauskaitè-Mažylienè. Partition: Niqab (2017) 


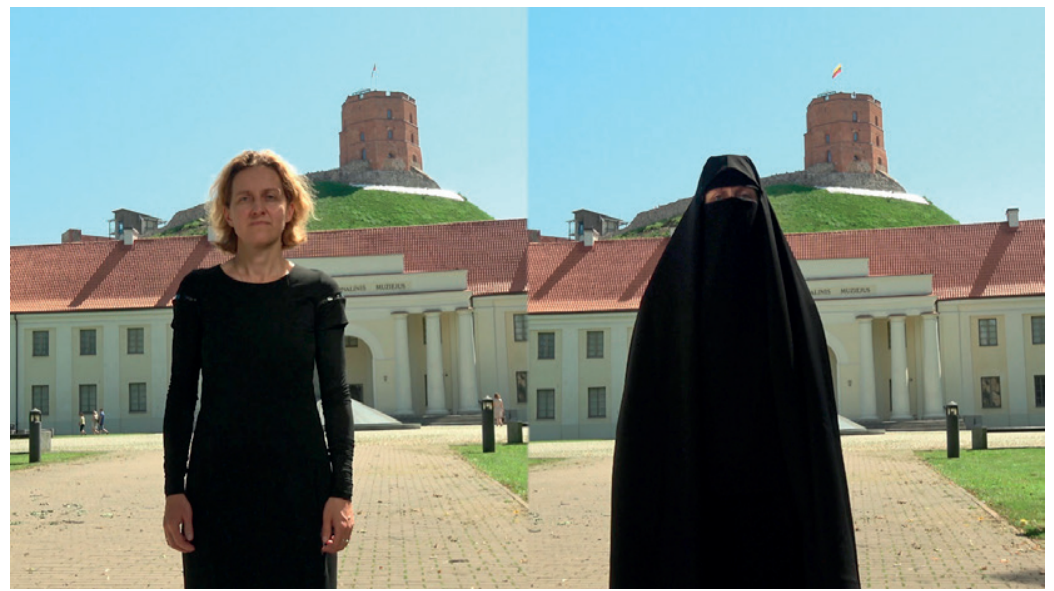

Figure 5. Sigita Maslauskaitè-Mažylienè. Partition: Niqab (2017)

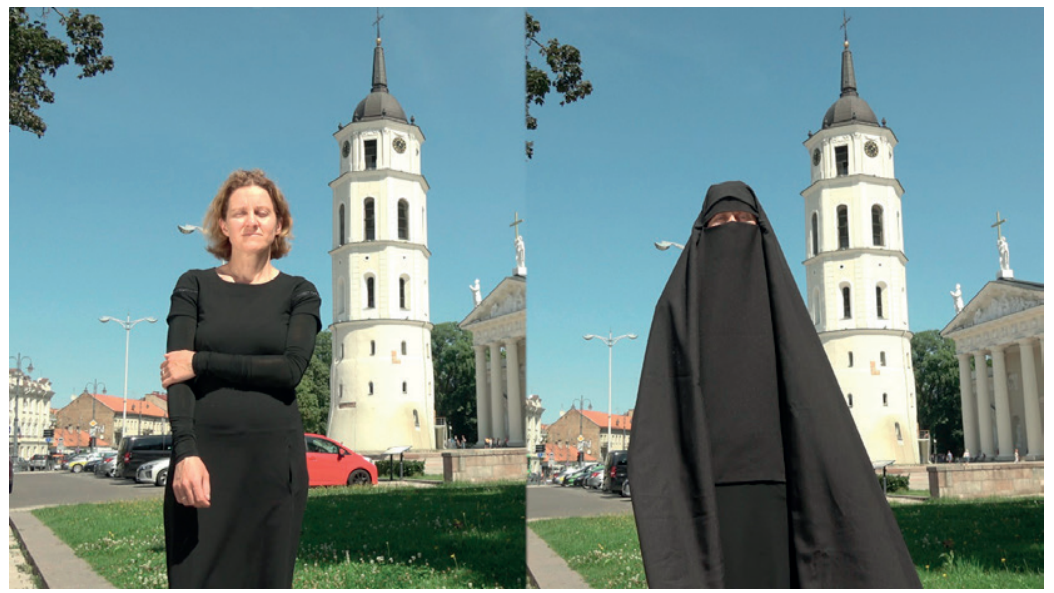

Figure 6. Sigita Maslauskaitè-Mažylienè. Partition: Niqab (2017)

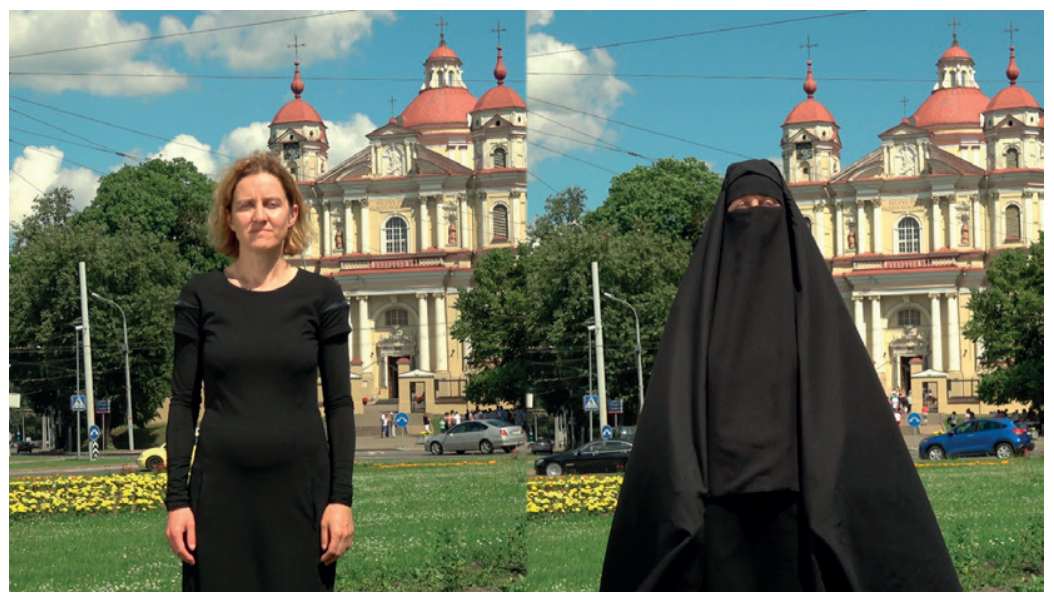

Figure 7. Sigita Maslauskaitè-Mažylienè. Partition: Niqab (2017) 
For her, the video installation was interesting for two reasons: the reaction of people and her own "experience of monitoring through a narrow gap in the headwear". MaslauskaitèMažylienè repeated the performance with the niqab at Lithuanian Railway Museum in May 2018. The artist remembers,

\begin{abstract}
"in the wagon where I sat, every third passenger was afraid to get on board, mothers tried to explain to their children that this was simply 'a human being', and some foreigners asked what my name was and why I stayed there. She found that through this short journey with a niqab her personal space was more overwhelming than without it: 'it is interesting to observe the world and people, and to know that they do not see you, do not recognize; as a woman I feel safe in all senses, as an outsider, I feel that I am interesting and scary"” (Maslauskaitė-Mažylienė \& Nikiforova, 2018).
\end{abstract}

In my view, this artistic performance has a strong element of SA.

To my question on what the artist thinks about conjuncture in contemporary art and how much the media as well as social and political discourses influence her creativity, I received a rather pessimistic answer:

"After my project By the Rivers of Babylon. Refugees and Deportees there were no consequences with the conjuncture. Nothing happened. I was left completely unnoticed: either a Seimas member, nor an embassy, ecclesiastical institution or refugee center asked to show the exhibition and video installations. Therefore, in this sense, I am absolutely clean. Perhaps we could even ask why?" (Maslauskaitė-Mažylienè \& Nikiforova, 2018).

\title{
Conclusions
}

The migrant is a political figure of our time. The figure of the migrant is not a "type of person" or fixed identity but a mobile social spectrum in which people move into and out under certain social conditions of mobility. The figure of the migrant is a political concept that defines the conditions and agencies by which various figures are socially expelled because of, or as the cause of, their mobility. Up till now, this kinetic history has led researchers and policymakers to a search for alternatives which would be mostly aimed at opposing the dominant forms of kinopolitical expulsion.

The migrants' expulsion can be used to understand contemporary migration. The social conditions of migration are always a result of mixing and weaving of territorial, political, juridical, and economic types of expulsion. We live in the century of the migrant not only thanks to quantitative indicators but also because all the previous forms of social expulsion and migratory resistance become more active than ever before. In addition, ecological crises and environmental refugees start to be another powerful source for migration crises.

The FM constantly balances between image and performativity. PHR is an attempt to look on the FM as a MW. The latest discussions on the topics of border, migration crises and refugees are in large part centered on the questions of AA and art creativity. VAs use posthuman performance as a type of interventionism in social and political life, which is partly aestheticized and spectacularized. The Debordian idea that an event in the real world, after being transferred into image, becomes a real and effective motivation for action, is 
acknowledged and reaffirmed in the described art cases. Their creativity is linked to other, sometimes alternative qualities of imagination, thinking and feeling, such as flexibility and tolerance of ambiguity or unpredictability.

We look on creativity as a condition, ability, source and linkage which enables us to view things in new ways or from a different perspective and to generate new possibilities or new alternatives through the world's ongoing intra-activity of art practice. These coerced cases show that creative art sometimes has great possibilities to make an effort to change the world through image. The artists' creativity helps us to recognize that the figure of the migrant has always been the true motive force of human history.

\section{References}

Barad, K. (2007). Meeting the universe halfway: quantum physics and the entanglement of matter and meaning. Durham, London: Duke University Press. https://doi.org/10.1215/9780822388128

Barad, K. (2003). Posthumanist performativity: toward an understanding of how matter comes to matter. Signs: Journal of Women in Culture and Society, 28(3), 801-831. https://doi.org/10.1086/345321

Belting, H. (2014). An anthropology of images: picture, medium, body. Princeton \& Oxford: Princeton University Press.

Belting, H. (2005). Image, medium, body: a new approach to iconology. Critical Inquiry, 31(2), 302-319. https://doi.org/10.1086/430962

Braidotti, R. (2016). Posthuman affirmative politics. In S. E. Wilmer \& A. Žukauskaite (Eds.), Resisting biopolitics: philosophical, political, and performative strategies (pp. 30-56). Series: Routledge Studies in Contemporary Philosophy. New York and London: Routledge.

Braidotti, R. (2013). Yes, there is no crisis. Working towards the posthumanities. International Journal for History, Culture and Modernity, 1(2), 187-199. https://doi.org/10.18352/hcm.412

Butler, J. (2009). Frames of war: when is life grievable? London, New York: Verso.

Debord, G. (1998). Comments on the society of the spectacle. London: Verso.

Debord, G. (1995). The society of the spectacle. New York: Zone Books.

Deleuze, G., \& Guattari, F. (1983). Anti-Oedipus: capitalism and schizophrenia. Minneapolis: University of Minnesota Press.

Groys, B. (2014). On art activism. E-Flux Journal 56. Retrieved from http://worker01.e-flux.com/pdf/ article_8984545.pdf

Kalinauskaite, M. (2017). Senos istorijos. Sigitos Maslauskaites-Mažylienes paroda „Prie Babilonijos upių. Pabègèliu laiškai“. Retrieved from https://www.15min.lt/kultura/naujiena/vizualieji-menai/senos-istorijos-sigitos-maslauskaites-mazylienes-paroda-prie-babilonijos-upiu-pabegeliulaiskai-929-820940

Kolossov, V. (2005). Border studies: changing perspectives and theoretical approaches. Geopolitics, 10(4), 606-632. https://doi.org/10.1080/14650040500318415

Maslauskaitè-Mažylienė, S., \& Nikiforova, B. (2018). Refugees and deportees in the visual arts (personal interview) (unpublished source).

Nail, Th. (2015). The figure of the migrant. Stanford, CA: Stanford University Press.

Nail, Th., \& Settle, Th. Z. (2016). Kinopolitics and the figure of the migrant: an interview with Thomas Nail. The Other Journal: An Intersection of Theology \& Culture 27. Retrieved from https://theotherjournal.com/2016/11/28/kinopolitics-figure-migrant-interview-thomas-nail/

Papastergiadis, N. (2000). The turbulence of migration. Cambridge: Polity Press. 
Rydgren, J. (2008). Immigration sceptics, xenophobes or racists? Radical Right-Wing voting in six West European Countries. European Journal of Political Research, 47(6), 737-765. https://doi.org/10.1111/ j.1475-6765.2008.00784.x

Rydgren, J. (2017). Radical Right-Wing parties in Europe: what's populism got to do with it? Journal of Language and Politics, 16(4), 485-496. https://doi.org/10.1075/jlp.17024.ryd

Rydgren, J. (2004). The logic of xenophobia. Rationality and Society, 16(2), 123-148. https://doi. org/10.1177/1043463104043712

Westmoreland, M. W. (2016). A roundtable on: Thomas Nail. The figure of the migrant. Stanford University Press, 2015. PhonEx, 11(1), 141-162.

Wieringa, T. (2012). These are the names. Brooklyn, London: Melville House.

\title{
EUROPIETIŠKOJO POSTHUMANISTINIO PARIBIO \\ IVAIZDIS: PERFORMATYVUMAS, KÜRYBIŠKUMAS IR ANAPUS
}

\section{Basia NIKIFOROVA}

\begin{abstract}
Santrauka
Menininkų supratimu, paribys - tai ne tik fizinè realybė, landšaftui primesta politinių jègų, bet ir vaizduotès bei kūrybiškumo, reprezentacijos ir vizualizacijos subjektas. Vizualiesiems menams yra svarbu pristatyti migraciją, pabėgèlius bei augančias naujas etnines ir religines bendruomenes. Mūsų užduotis - apsvarstyti koreliatyvumą tarp naujos miesto paribio formos ir reteritorizacijos bei jų materializuoto vizualinio įvaizdžio, reflektuoti pusiausvyrą tarp pretenzijų i skirtumą ir vienodumą bei dinamiką tarp vyraujančio supratimo apie tai, kaip pabègèliai reprezentuoja pačius save. Šiais laikais medijose susiduriame su deboriškuoju spektakliu, redukuojančiu realybę ị begalinę fragmentaciją, skatinančią mus susitelkti ị regimybes. Thomasas Neilas pažymi, kad migrantas tapo politine mūsų laikų figūra, o migranto fenomenas ragina mus iš naujo apmąstyti fundamentalią politinę, kultūros ir meno filosofiją. Svarbu atskleisti naujųjų diskursų ir meno praktikų tarpusavio ryšius, reflektuojant vietinį lietuviškąji migravimo proceso įvaizdị. Tad straipsnyje plètojamame atvejo tyrime pristatoma Sigitos Maslauskaitės-Mažylienės meno darbų analizė bei meno praktikos kaip svarbūs diskursyvūs procesai ir kultūrinès reikšmès.
\end{abstract}

Reikšminiai žodžiai: paribys, kūrybiškumas, ịvaizdis, migracija, reprezentacija, reteritorizacija, vizualieji menai. 